\title{
Budidaya Tanaman Seledri Di Dalam Pot Dan Manfaatnya Untuk Kesehatan
}

\author{
Yetti Elidar \\ Universitas Mulawarman Samarinda \\ elidaryetti@gmail.com
}

\begin{abstract}
Abstrak
Tanaman seledri merupakan sayuran yang memiliki banyak manfaat yaitusebagai pelengkap masakan dan memiliki khasiat sebagai obat. Seledri merupakan tumbuhan obat yang telah menjadi produk fitofarmaka, yaitu obat bahan alam yang telah memenuhi criteria aman sesuai dengan persyaratan yang ditetapkan, khasiatnya telah dibuktikan secara klinis dan bahan baku yang digunakan dalam produk jadinya telah melalui proses standardisasi. Seledri diindikasikan untuk menurunkan tekanan darah dan dapat digunakan dalam pengobatan hipertensi ringan (BPOM, 2008). Di Indonesia produksi seledri terkendala oleh terbatasnya luas lahan produktif sehingga pilihan teknologi yang tepat untuk mengatasi masalah ini adalah teknologi budidaya di dalam pot atau polybag.
\end{abstract}

Keywords: Budidaya dalam Pot, Seledri, Kesehatan 


\section{Jurnal Abdimas Mahakam \\ https://journal.uwgm.ac.id/index.php/abdimasmahakam \\ Online ISSN : 2549-5755 \\ Januari 2018, Vol. 2 No. 1}

\section{Pendahuluan}

Seledri (Apium graveolens L.) sudah dikenal masyarakat Indonesia. Tanaman seledri dimanfaatkan sebagai sayuran bumbu (penyedap rasa), juga sebagai obat, penyembuh demam dan darah tinggi, dan sebagai penyubur rambut.

Tanaman seledri tergolong dalam family Umberliflorae. Di Indonesia tanaman seledri yang di kenal ada dua varietas yaitu : seledri potong (Varietas Sylvester) dan seledri daun (Varietas Secalium). Masih ada satu jenis lagi tetapi jarang ditemui yaitu seledri berumbi (Varietas Repaceum).

Diantara ketiga varietas seledri daun yang paling banyak dibudidayakan petani adalah jenis seledri daun (Cut Common). Varietas ini mempunyai cirri diantaranya tanamannya pendek, daunnya banyak, juga anakannya cukup banyak. Benih seledri yang banyak ditemui di toko pertanian antara lain Amigo (East West), produk Royal Sluis dan sebagainya.

Usaha tani seledri dapat dilakukan dengan hasil yang sempurna pada dataran tinggi (1000 $1200 \mathrm{~m} \mathrm{dpl}$ ). Seledri juga ditanama pada dataran rendah karena tanaman ini masih toleran mengalami pertumbuhan di dataran rendah. Tanaman seledri tidak tahan pada curah hujan yang tinggi.

Tanaman seledri dapat dimanfaatkan sebagai obat tradisional untuk memperlancar pencernaan, penyembuhan demam, flu, penambah nafsu makan (Fazal dan Singla, 2012), dan penurun tekanan darah tinggi (Muzakar dan Nuryanto, 2012). Kandungan senyawa kimia dalam herba seledri memiliki aktivitas sebagai anti mikroba (Sipailiene et al., 2003), anti hipertensi (Dewi dkk., 2010), antioksidan (Jung, et al., 2011), anti ketombe (Mahataranti dkk., 2012), antidepresan (Desu and Sivarama khrisna, 2012), dan anti-inflamasi (Arzi et al., 2014).

Tujuan Pengabdian kepada Masyarakat

1. Memberikan pengetahuan budidaya tanaman seledri dalam pot dan manfaatnya untuk kesehatan.

2. Memberikan pengetahuan cara pengolahan daun seledri untuk kesehatan. 


\section{Jurnal Abdimas Mahakam \\ https://journal.uwgm.ac.id/index.php/abdimasmahakam \\ Online ISSN : 2549-5755 \\ Januari 2018, Vol. 2 No. 1}

Manfaat Pengabdian kepada Masyarakat

Sumbangan informasi bagi pemerintah dalam mewujudkan gerakan masyarakat sehat di tingkat keluarga.

\section{Metode}

A. Waktu dan Tempat

Kegiatan Pengabdian kepada Masyarakat (Penyuluhan) dilaksanakan selama 1 hari di Kelurahan Lempake, Kecamatan Samarinda Utara.

B. Peserta

Peserta Pengabdian kepada Masyarakat (Penyuluhan) adalah kelompok masyarakat yang terdiri dari para ibu rumah tangga.

C. Metode Penyuluhan

Penyuluhan dilakukan melalui metode :

1. Pemberian teori tentang budidaya tanaman seledri dalam pot

Sebagai dasar pengetahuan yang berguna untuk mendukung keberhasilan kegiatan penyuluhan.

2. Demonstrasi pengolahan daun seledri.

\section{Hasil dan Pembahasan}

\section{A. Hasil}

Penyuluhan yang dilakukan masih pada tahap informasi yaitu memberikan pengetahuan mengenai pentingnya melakukan budidaya tanaman seledri di dalam pot untuk meningkatkan gizi keluarga dan apotik hidup serta untuk menjaga kesehatan melalui pengobatan secara herbal untuk mengatasi berbagai penyakit dan untuk meningkatkan pendapatan keluarga. 


\section{Jurnal Abdimas Mahakam \\ https://journal.uwgm.ac.id/index.php/abdimasmahakam \\ Online ISSN : 2549-5755 \\ Januari 2018, Vol. 2 No. 1}

Proses adaptasi masyarakat memerlukan waktu yang bervariasi, ada yang cepat mengadopsi dan ada yang lambat dengan keterbatasan waktu yang tersedia. Sehingga penyuluhan ini perlu dilanjutkan sampai pada tahap penerapan oleh para peserta.

Tingkat kesadaran masyarakat untuk melakukan budidaya tanaman seledri di dalam pot masih sangat terbatas namun masih memungkinkan untuk melakukan budidaya dalam pot mengingat pekarangan rumah masih tersedia cukup luas.

Budidaya tanaman seledri di dalam pot atau di lahan pekarangan memiliki peranan untuk meningkatkan keanekaragaman hasil tanaman pekarangan dan dapat memenuhi gizi keluarga serta kesehatan keluarga. Pekarangan diharapkan mampu memenuhi kebutuhan gizi keluarga sehingga dapat menekan biaya kesehatan keluarga dan mendukung gerakan masyarakat sehat.

Tingkat kesadaran masyarakat masih rendah untuk memanfaatkan pekarangan dengan budidaya tanaman seledri di dalam pot meskipun ketersediaan benih ataupun bibit mudah diperoleh. Pekarangan diharapkan dapat dioptimalkan pemanfaatannya untuk memenuhi kebutuhan gizi dan apotik hidup atau pengobatan herbal sebagai upaya pencegahan berbagai macam penyakit di tingkat keluarga.

\section{B. Pembahasan}

Hasil penyuluhan menunjukkan perlu dilakukan penyuluhan tentang budidaya tanaman seledri dalam pot untuk meningkatkan kebutuhan gizi keluarga dan pendapatan rumah tangga.

Hal ini mengingat pentingnya budidaya tanaman seledri dalam pot yang memiliki manfaat untuk menunjang kesehatan dan dapat dimanfaatkan sebagai usaha untuk meningkatkan pendapatan keluarga atau alternative wirausaha bidang pertanian serta dapat menciptakan lingkungan yang sehat dan asri.

Pekarangan rumah dapat dimanfaatkan untuk budidaya tanaman dalam pot dan memiliki arti yang sangat penting bagi pemiliknya. Pekarangan rumah yang tidak terlalu luas apabila dikelola dengan baik akan menghasilkan sesuatu yang bernilai tinggi. Pekarangan rumah atau lahan kebun dapat dimanfaatkan secara efisien dengan budidaya tanaman seledri maupun 


\section{Jurnal Abdimas Mahakam \\ https://journal.uwgm.ac.id/index.php/abdimasmahakam \\ Online ISSN : 2549-5755 \\ Januari 2018, Vol. 2 No. 1}

tanaman buah dan tanaman hias. Menurut Herlina (2017), beberapa keuntungan menanam sayuran organik dalam polybag, yaitu : a) dapat dilakukan dalam skala kecil atau rumah tangga, b) mudah pemeliharaannya, c) penanganan hama dan penyakit lebih mudah, dan d) hemat dalam pemakaian pupuk (tidak terbuang percuma).

Tanaman seledri dipanen umur 6-8 minggu setelah tanam yaitu dengan memanen daun yang tidak terlalu tua dan tidak terlalu muda. Seledri juga dapat dipanen beberapa kali hingga mencapai umur 5 bulan dan biasanya satu tanaman dapat dipanen 6-8 helai daun atau dipanen dengan dipotong pangkal batang tepat di atas akar (Penyuluh Pertanian, 2017).

Seledri merupakan tanaman obat yang memiliki khasiat bagi kesehatan. Seledri mengandung beberapa zat yang bermanfaat untuk menurunkan tekanan darah, meliputi apiin, manitol, apigenin, dan potassium. Selain itu seledri juga memiliki kandungan alami untuk menurunkan kadar kolesterol di dalam darah yaitu fitosterol yang mencegah deposisi kolesterol pada dinding dalam pembuluh darah.

Trend masyarakat kembali ke alam (back to nature) dalam dunia pengobatan telah meningkatkan pertumbuhan obat herbal. Secara empiris daun seledri berkhasiat sebagai obat hipertensi, asma, diabetes, rematik, radang, asam urat dan penurun kolesterol. Kandungan serat daun seledri yang tinggi dan aromanya yang agak menyengat, maka penggunaannya dengan cara dicincang dan dicairkan, sehingga lebih mudah dicerna dalam tubuh (Widisih, 2003).

\section{Simpulan dan rekomendasi}

Dari hasil penyuluhan dapat diambil kesimpulan sebagai berikut :

1. Pengetahuan masyarakat tentang budidaya tanaman seledri dalam pot dan manfaatnya untuk kesehatan semakin meningkat.

2. Masyarakat mengetahui cara pengolahan daun seledri untuk meningkatkan gizi keluarga dan sebagai pengobatan herbal. 
Jurnal Abdimas Mahakam

https://journal.uwgm.ac.id/index.php/abdimasmahakam

Online ISSN : 2549-5755

Januari 2018, Vol. 2 No. 1

\section{Daftar Pustaka}

BPTP Jambi. 2012. Teknologi Budidaya Seledri dalam Pot. http://jambi.litbang.pertanian.go.id/eng/images/PDF/12seledri.pdf. Diunduh15 September 2017.

Herlina, C.N. 2017. Sayuran Organik dalam Pot dan polybag. https://http://nad.litbang.pertanian.go.id/ind/images/dokumen/Bulletin/05sayuranorganik.pdf. Diunduh15 September 2017.

Penyuluh Pertanian. 2017. Budidaya Seledri. http://penyuluhpertanian.net/wpcontent/uploads/2016/12/10.-folder-Budidaya-Seledri.pdf. Diunduh15 September 2017. 